\title{
Recycling Bitumen from Dismantled Road-A Case Study
}

\author{
Monika Dagliya \\ Department of Civil Engineering \\ Prestige Institute of Engineering Management \& Research \\ (Sch. No. 74, Vijay Nagar, Indore (M.P.)
}

\author{
Rewa Bochare \\ Department of Civil Engineering \\ Prestige Institute of Engineering Management \& Research \\ (Sch. No. 74, Vijay Nagar, Indore (M.P.)
}

\begin{abstract}
In a developing country like India, many changes in urban planning and infrastructure facilities are proposed and brought into practice on a daily basis. One such commonly faced challenge is the proper handling of demolished pavements during road construction and rehabilitation. Also if the demolished pavement is not disposed off in the correct manner, it may cause serious environmental hazard. A possible solution to this is the reusing of demolished materials by recycling in proper manner. The solution, not very commonly adopted in India may become a possible alternative for pavement construction for the current ambitious road building programme underway. The present study involves the recycling of existing asphalt pavement materials of a dismantled road at Indore, India to produce new pavement materials. The results showed considerable savings of material, money, and energy.
\end{abstract}

Keywords - Infrastructure; pavement; recycling; environmental hazard

\section{INTRODUCTION}

Over the years, recycling has become one of the most attractive pavement rehabilitation alternatives in developed countries. Unfortunately, asphalt pavement recycling is yet to take off in India despite the current ambitious road building programmed underway.

Recycling of existing asphalt pavement materials to produce new pavement materials results in considerable savings of material, money, and energy. The specific benefits of recycling can be summarized as follows:

(a) Substantial savings over the use of new materials,

(b) Conservation of natural resources,

(c) Performance equal or even better than new materials,

(d) Pavement geometrics is maintained, and

(e)Saving of considerable amount of energy compared to conventional construction techniques.

The last benefit is very important due to the recent urgent need for reducing greenhouse gases that is, reducing carbon footprint thereby earning carbon credits for India.

The Asphalt Recycling and Reclaiming Association define five different types of recycling methods: (1) Cold Planning; (2) hot recycling; (3) Hot in Place Recycling; (4) Cold In-Place Recycling; and (5) Full Depth Reclamation. Only hot recycling of asphalt pavements at a central plant will be discussed in this article in the context of 4-laning and 6-laning of India's state highways and national highways wherein road paving bitumen worth crores of rupees is being buried rather than recycled.

\section{LITERATURE REVIEW}

Arvind and Das (2006) adopted central plant hot mix recycling for recycling of asphalt pavement materials. Literature review reports varied levels of performances (laboratory as well as field) of recycled mix compared to the performances of corresponding virgin mixes. Thus, they conducted performance-related tests before finalizing any recycled mix design. They conducted laboratory study on recycled mix design of two different Reclaimed Asphalt Pavement (RAP) samples, and subsequently developed an integrated mix-design-structural-design approach for hot recycled mix. The total cost of the asphalt layer construction was estimated considering the constituent proportion and the pavement design thickness so that the designer may choose the best option.

Shunyashree, et al proposed that recycling of asphalt pavements is one of the effective and proven rehabilitation processes. For the laboratory investigations reclaimed asphalt pavement (RAP) from NH-4 and crumb rubber modified binder (CRMB-55) was used. Foundry waste was used as a replacement to conventional filler. Laboratory tests were conducted on asphalt concrete mixes with 30, 40, 50, and 60 percent replacement with RAP. These test results were compared with conventional mixes and asphalt concrete mixes with complete binder extracted RAP aggregates. Mix design was carried out by Marshall Method. The Marshall Tests indicated highest stability values for asphalt concrete (AC) mixes with $60 \%$ RAP. The optimum binder content (OBC) decreased with increased in RAP in AC mixes. The Indirect Tensile Strength (ITS) for AC mixes with RAP also was found to be higher when compared to conventional AC mixes at 30 ${ }^{\circ} \mathrm{C}$.Thus these previous studies were referred to before conducting the tests in this study. 


\section{METHODOLOGY}

A sample of the bituminous layer was collected from the dismantled road at Malwa mill area in Indore. The sample was broken into small pieces, washed with water and then dried for one day. An amount of 250 grams of the washed sample was taken out for performing the bitumen extractor test to determine the initial bitumen content. Aggregates of different sizes were purchased from the market. Sieve Analysis was performed on each sample of the aggregates procured from the market. Grading of material was done according to section 509 of MORTH (Ministry of Road Transport and Highways) code. Samples of different grades of materials were then weighed (1200 grams each). Aggregate sample was then heated up to $160^{\circ} \mathrm{C}$ and then cooled up to $140^{\circ} \mathrm{C}$ in a pan. Another sample of heated bitumen grade of 60-70 was added to the heated material and then mixed. Mould was prepared with varying percentages bitumen content. Marshall Stability test (Figure 1) was performed for each sample having different percentage bitumen content to determine stability and flow value, voids in aggregate (VA), voids in mineral aggregate (VMA), and voids filled with bitumen (VFB) as given in MORTH.

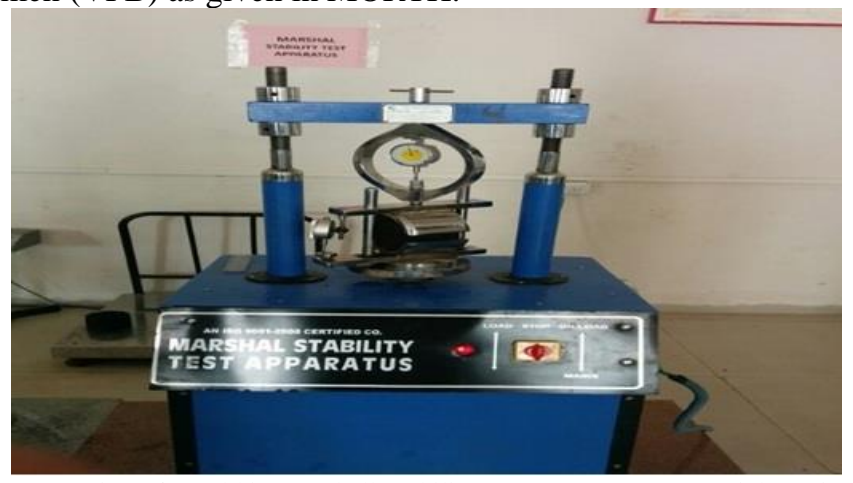

Figure 1: Testing of mould in Marshall Stability test apparatus at Material Testing Lab

Optimum bitumen content was determined from stability and flow value. Washed and dried Malwa Mill road material passed from $12.5 \mathrm{~mm}$ I.S. sieve and retained on $10 \mathrm{~mm}$ sieve was taken. Material was then weighed and then heated up to $160^{\circ} \mathrm{C}$ and then cooled upto $140^{\circ} \mathrm{C}$. Required bitumen content was added to the material and then mixed to prepare moulds as shown in Figure 2.

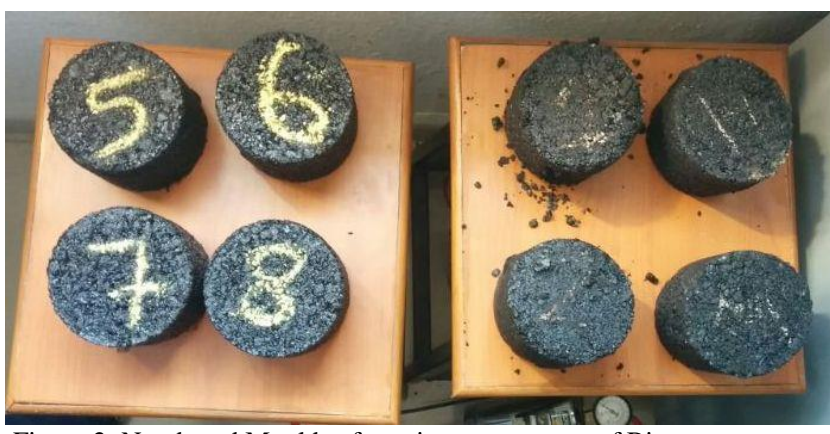

Figure 2: Numbered Moulds of varying percentages of Bitumen contents

Marshall Stability test was preformed for these samples to determine stability and flow value. Stability and flow value of each sample was compared. Result analysis and cost analysis was done. Conclusions were derived from the same.

\section{RESULTS}

Sieve Analysis on aggregates $4.75 \mathrm{~mm}, 6 \mathrm{~mm}$, stone dust and cement were first performed in the material testing laboratory as prescribed by Indian Standards.

As an example a sample table for sieve analysis of cement is given below in the form of Table 1 .

Table 1: Sieve Analysis of cement sample

\begin{tabular}{|c|c|c|c|c|}
\hline $\begin{array}{c}\text { Sieve } \\
\text { size }\end{array}$ & $\begin{array}{c}\text { Weight } \\
\text { retained }\end{array}$ & $\begin{array}{c}\text { Percentage } \\
\text { retained }\end{array}$ & $\begin{array}{c}\text { Cumulative } \\
\text { frequency }\end{array}$ & $\begin{array}{c}\text { Percentage } \\
\text { passing }\end{array}$ \\
\hline $600 \mu$ & 0 & 0 & 0 & 100 \\
\hline $300 \mu$ & 0 & 0 & 0 & 100 \\
\hline $150 \mu$ & & 0 & 0 & 100 \\
\hline $75 \mu$ & & 94 & 94 & 6 \\
\hline
\end{tabular}

According to IRC 29-1968 specifications, the mineral aggregates including mineral filler should be so graded or combined so as to confirm to the grading. Unless otherwise specified, for compacted layer thickness of 24 to $40 \mathrm{~mm}$, any of the two grading can be used, but for layer thickness of 40 to $50 \mathrm{~mm}$, only grading no.2 can be used. 
Table 2 gives the aggregate gradation for bituminous concrete.

First the initial bitumen contained for the sample was calculated by bitumen extractor. Then the optimum bitumen contained by marshal stability test, and finally the required bitumen to be added in sample was calculated.

Table 3 gives the results of sieve analysis for bituminous concrete.

Table 2: Aggregate gradation for bituminous concrete

\begin{tabular}{|c|c|c|}
\hline \multirow{2}{*}{ Sieve designation } & \multicolumn{2}{|c|}{ Percent by weight passing the sieve } \\
\cline { 2 - 3 } & Grading 1 & Grading 2 \\
\hline $20 \mathrm{~mm}$ & - & 100 \\
\hline $12.5 \mathrm{~mm}$ & 100 & $80-100$ \\
\hline $10 \mathrm{~mm}$ & $80-100$ & $70-90$ \\
\hline $4.75 \mathrm{~mm}$ & $55-75$ & $50-70$ \\
\hline $2.36 \mathrm{~mm}$ & $35-50$ & $35-50$ \\
\hline $600 \mathrm{micron}$ & $18-29$ & $18-29$ \\
\hline 300 micron & $13-23$ & $13-23$ \\
\hline 150 micron & $8-16$ & $8-16$ \\
\hline 75 micron & $4-10$ & $4-10$ \\
\hline
\end{tabular}

Table 3 : Sieve Analysis for bituminous concrete

\begin{tabular}{|c|c|c|c|c|c|c|c|}
\hline Sieve designation & Aggregate $6 \mathrm{~mm}$ & Aggregate $4.75 \mathrm{~mm}$ & Stone dust & Filler cement & Blended grading & Desired grading & Remark \\
\hline $12.5 \mathrm{~mm}$ & 100 & 100 & 100 & 100 & 100 & 100 & $\mathrm{Ok}$ \\
\hline $10 \mathrm{~mm}$ & 100 & 100 & 100 & 100 & 100 & $80-100$ & Ok \\
\hline $4.75 \mathrm{~mm}$ & 27.01 & 91.54 & 77.98 & 100 & 74.33 & $55-75$ & $\mathrm{Ok}$ \\
\hline $2.36 \mathrm{~mm}$ & 1.16 & 42.17 & 46.85 & 100 & 41.73 & $35-50$ & $\mathrm{Ok}$ \\
\hline 600 & 0.34 & 3.99 & 21.25 & 100 & 18 & $18-29$ & Ok \\
\hline 300 & 0.24 & 0.32 & 15.89 & 100 & 13.35 & $13-23$ & $\mathrm{Ok}$ \\
\hline 150 & 0.18 & 0.2 & 7.68 & 100 & 8 & $8-16$ & Ok \\
\hline 75 & 0.10 & 0 & 3.16 & 94 & 4.13 & $4-10$ & $\mathrm{Ok}$ \\
\hline Mixing \% & 12 & 15 & 71 & 2 & & & \\
\hline
\end{tabular}

The obtained bitumen mix was compared with the standard requirements and the results of the same have been summarized in Table 4 .

Also a clear comparison between old sample and new sample has been given in Table 5 for two parameters viz. stability and flow for different bitumen content.

Also the variation of strength and flow parameters with varying bitumen content has been further indicated graphically in Figure 3 and Figure 4 respectively.

Table 4: Requirements of bituminous concrete mix

\begin{tabular}{|c|c|c|c|}
\hline $\begin{array}{c}\text { Serial } \\
\text { No. }\end{array}$ & Description & Requirement & Obtained \\
\hline 1 & $\begin{array}{l}\text { Marshal stability (ASTM designation D 1599) determined in Marshall specification compacted by } 50 \\
\text { compaction blows on each end. }\end{array}$ & $\begin{array}{l}340 \mathrm{~kg} \\
\text { minimum }\end{array}$ & $390 \mathrm{~kg}$ \\
\hline 2 & Marshall flow (25mm) & $8-16$ & 15 \\
\hline 3 & Per cent voids in mix & $3-5$ & 3.94 \\
\hline 4 & Per cent voids in mineral aggregate filled with bitumen & $75-85$ & 81.25 \\
\hline 5 & Binder content per cent by weight of mix & $5-7.5$ & 6.5 \\
\hline
\end{tabular}

Table 5: Comparison of fresh material and old material

\begin{tabular}{|c|c|c|c|c|c|}
\hline $\begin{array}{c}\text { Bitumin } \\
\text { content (\%) }\end{array}$ & 4.5 & 5.5 & $\begin{array}{c}6.5(\text { new } \\
\text { sample) }\end{array}$ & $\begin{array}{c}6.5(\text { old } \\
\text { sample) }\end{array}$ & 7.5 \\
\hline Stability (k.G.) & 490 & 540 & 580 & 390 & 500 \\
\hline Flow(mm) & 8 & 10 & 13 & 10 & 15 \\
\hline
\end{tabular}




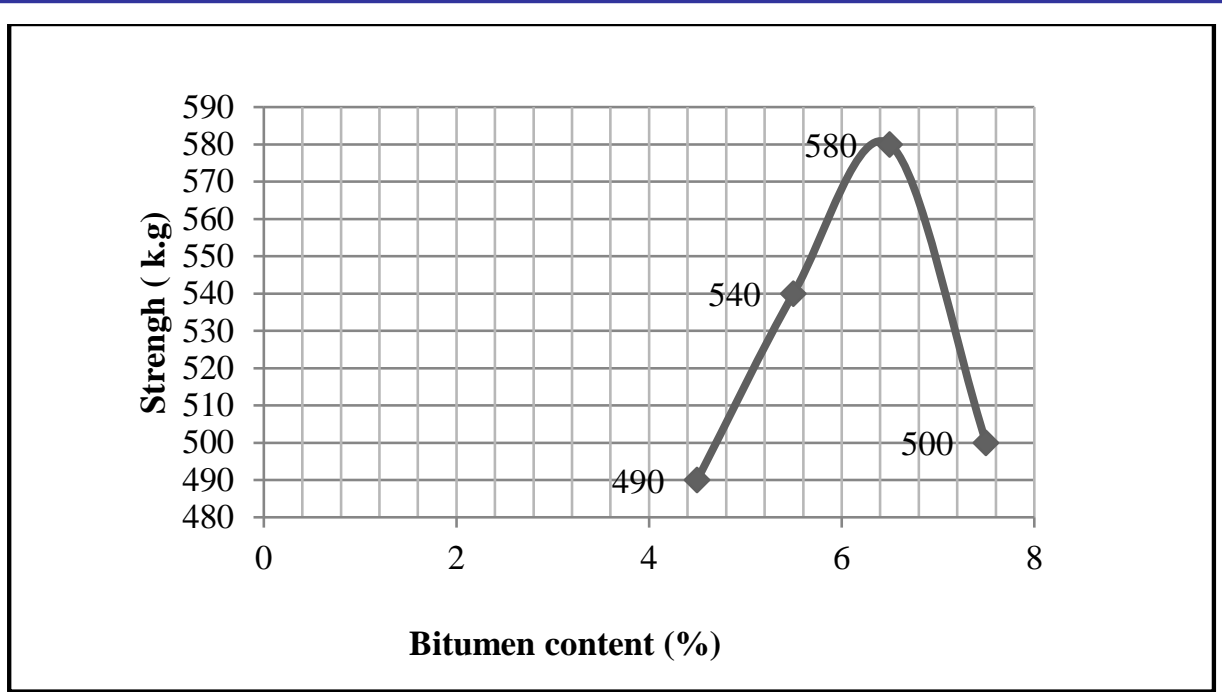

Figure 3 Bitumen content v.s. Strength curve

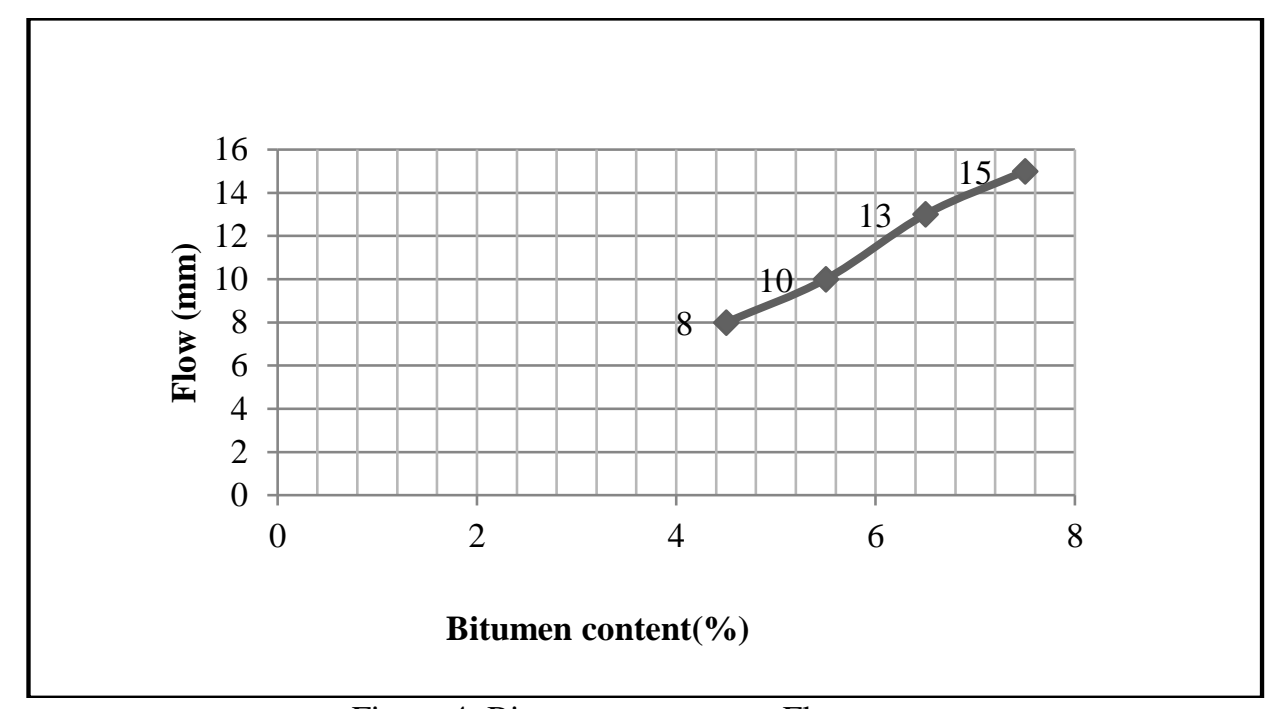

Figure 4: Bitumen content v.s. Flow curve

The density of the sample $(\mathrm{G})$ was found to be $=2.44$. The specific gravity of the total blended mineral was calculated after determining the specific gravities of different aggregate used in the mix.

Where $\mathrm{G}_{\mathrm{a}}$ = specific gravity of combined aggregate.

$$
\mathrm{G}_{\mathrm{a}}=100 /\left(\mathrm{W}_{1} / \mathrm{g}_{1}+\mathrm{W}_{2} / \mathrm{g}_{2}+\mathrm{W}_{3} / \mathrm{g}_{3}+\mathrm{W}_{4} / \mathrm{g}_{4}\right)
$$

$\mathrm{W}_{1} \mathrm{~W}_{2 \ldots}=$ respective per cents by weight of aggregate $1,2,3$.

$\mathrm{g}_{1}, \mathrm{~g}_{2}=$ respective specific gravities of aggregate $1,2,3$.

$\mathrm{W}_{4}$ and $\mathrm{g}_{4}=$ weight and specific gravity of binder material.

The value was calculated as $\mathrm{G}_{\mathrm{a}}=2.85$. The theoretical maximum specific gravity which is the theoretical density of a void less mixture of a bituminous paving mix may be expressed as follows:

$$
\mathrm{G}_{\mathrm{t}}=100 /\left(\left(100-\mathrm{W}_{\mathrm{b}}\right) / \mathrm{G}_{\mathrm{a}}+\mathrm{W}_{\mathrm{b}} / \mathrm{g}_{\mathrm{b}}\right)
$$

where $\mathrm{G}_{\mathrm{t}}=$ maximum theoretical specific gravity at $25^{\circ} \mathrm{C}$. and $\mathrm{W}_{\mathrm{b}}=$ bitumen content, per cent by weight The calculated value of $\mathrm{G}_{\mathrm{t}}=2.54$.

Per cent of maximum density of the mix $(\mathrm{M})$ was calculated as $96.06 . \mathrm{V}_{\mathrm{a}}=$ per cent voids in specimen $=3.94$

$\mathrm{VMA}=$ voids in mineral aggregate $(\mathrm{VMA})=21.55$

$\mathrm{VFB}=$ per cent voids, filled with bitumen $=81.25$

Table 6 below gives the abstract sheet of recycled material followed by Table 7 which is the abstract sheet of the fresh material. 
Table 6: Abstract sheet of recycled material

\begin{tabular}{|c|c|c|c|c|c|c|c|c|c|c|}
\hline $\begin{array}{c}\text { Item } \\
\text { no }\end{array}$ & Particulars of items & Quantity & Unit & Rate & Qty & $\begin{array}{l}\text { Quantity } \\
\text { saved }\end{array}$ & Quantity & Unit & Cost & $\begin{array}{c}\text { Cost } \\
\text { saved }\end{array}$ \\
\hline 1 & Aggregate $6 \mathrm{~mm}$ & 3.6 & $\mathrm{~m}^{3}$ & 650 & $\begin{array}{l}\text { per } \\
\mathrm{m}^{3}\end{array}$ & 3.6 & 3.6 & $\mathrm{~m}^{3}$ & 2340 & 2340 \\
\hline 2 & Aggregate $4.75 \mathrm{~mm}$ & 4.5 & $\mathrm{~m}^{3}$ & 630 & $\begin{array}{l}\text { per } \\
\mathrm{m}^{3}\end{array}$ & 4.5 & 4.5 & $\mathrm{~m}^{3}$ & 2835 & 2835 \\
\hline 3 & Stone dust & 21.3 & $\mathrm{~m}^{3}$ & 600 & $\begin{array}{l}\text { per } \\
\mathrm{m}^{3}\end{array}$ & 21.3 & 21.3 & $\mathrm{~m}^{3}$ & 12780 & 12780 \\
\hline 4 & Cement & 17.28 & bags & 280 & $\begin{array}{l}\text { per } \\
\text { bag }\end{array}$ & 17.28 & 17.28 & bags & 4838 & 4838 \\
\hline 5 & $\begin{array}{c}\text { Bitumen } 60 / 70 \text { grade } \\
\text { penetration }\end{array}$ & 1142.31 & $\mathrm{~kg}$ & 65 & $\begin{array}{l}\text { per } \\
\mathrm{kg}\end{array}$ & 827.19 & 1142.31 & $\mathrm{~kg}$ & 74250 & 53767 \\
\hline \multirow[t]{6}{*}{6} & $\begin{array}{c}\text { Washing of dismantled } \\
\text { material }\end{array}$ & 30 & $\mathrm{~m}^{3}$ & 371 & $\begin{array}{l}\text { per } \\
\mathrm{m}^{3}\end{array}$ & Nil & 30 & $\mathrm{~m}^{3}$ & 11137.5 & 0 \\
\hline & & & & & & & $\begin{array}{c}\text { Material } \\
\text { cost }\end{array}$ & & 108181 & 76560 \\
\hline & & & & & & & & $\begin{array}{c}\text { Add labour cost @ } 30 \% \text { of } \\
\text { total cost }\end{array}$ & 32454 & \\
\hline & & & & & & & & $\begin{array}{c}\text { Add contractors profit @ } 10 \\
\%\end{array}$ & 10818 & \\
\hline & & & & & & & Total cost & & 151453 & \\
\hline & & & & & & & $\begin{array}{c}\text { Overall } \\
\text { cost }\end{array}$ & & 74892 & \\
\hline
\end{tabular}

Table 7: Abstract sheet of fresh material

\begin{tabular}{|c|c|c|c|c|c|c|}
\hline Item no & Description & quantity & unit & rate & per & cost \\
\hline & $\begin{array}{l}\text { Providing and laying bituminous concrete with hot mix plant using crushed aggregates } \\
\text { of specified grading, premixed with bituminous binder, transporting the hot mix to } \\
\text { work site, laying with a mechanical paver finisher to the required grade, level and } \\
\text { alignment, rolling with smooth wheeled vibratory and tandem rollers to achieve the } \\
\text { desired compaction in all aspects and as per clauses of section- 509. (Only cement will } \\
\text { be use as filler). }\end{array}$ & & & & & \\
\hline 1 & For grading II (30-45 mm thickness ) with $60 / 70$ bitumen & 30 & $\mathrm{~m}^{3}$ & 8226 & $\mathrm{~m}^{3}$ & 246780 \\
\hline
\end{tabular}

\section{CONCLUSIONS}

- Cost of construction of bituminous concrete layer of 100 meter length, 7.5 meter wide and $4 \mathrm{~cm}$ thick (quantity $\left.30 \mathrm{~m}^{3}\right)$ is Rs 246780 only, while recycled dismantled road cost is Rs 74893. Thus a saving of around $70 \%$ is observed in cost incurred when recycled bitumen is used as a partial substitute of fresh concrete.

- The stability as well as flow values were found to be increased for new sample.

- It was found experimentally that around $70 \%$ of the bitumen of the dismantled road may be recycled and used for further pavement construction activities.

- This may also serve as a lucrative option for the disposal of bitumen for dismantled roads. As bitumen resulting in dump yards poses a serious threat to the environment, recycling of this bitumen can protect mankind from this ecological hazard.

\section{ACKNOWLEDGMENT}

The authors wish to thank Director and Staff of Prestige Institute of Engineering Management \& Research, Indore for their technical support during the tests performed in the laboratories in the Civil Engineering Department of the Institute.

\section{REFERENCES}

[1] Integrated Standard Schedule of rates (volume 3) road and bridges Department of Urban Administration and Development Madhya Pradesh in force from $10^{\text {th }}$ may 2013

[2] IRC (Indian Road Congress) 29-1968 specifications of bituminous concrete for roads.

[3] Lokesh Y, Mahendra SP. Study On the Effect of Stone, Dust, Ceramic Dust and Brick Dust as Fillers on the Strength, Physical and Durability Properties of Bituminous Concrete (BC-II) Mix. International Journal of Applied Engineering Research. 2018;13(7):203-8.

[4] Lokesh Y, Mahendra SP. Study On the Effect of Stone, Dust, Ceramic Dust and Brick Dust as Fillers on the Strength, Physical and Durability Properties of Bituminous Concrete (BC-II) Mix. International Journal of Applied Engineering Research. 2018;13(7):203-8.

[5] Gawande A, Zamre GS, Renge VC, Bharsakale GR, Tayde S. Utilization of waste plastic in asphalting of roads. Scientific Reviews \& Chemical Communications. 2012; 2:147-57.

[6] Button, J. W., Estakhri, C. K., \& Little, D. N. (1999). Overview of hot in-place recycling of bituminous pavements. Transportation research record, 1684(1), 178-185.

[7] Noureldin, A. S., \& Wood, L. E. (1987). Rejuvenator diffusion in binder film for hot-mix recycled asphalt pavement. Transportation research record, (1115).

[8] O'Leary, M. D., \& Williams, R. D. (1992). In situ cold recycling of bituminous pavements with polymer-modified high float emulsions. Transportation Research Record, (1342).

[9] McKinney, J. L. (1979). Recycling of Bituminous Pavements. 
[10] JONES, G. M. (1979). RECYCLING OF BITUMINOUS PAVEMENTS ON THE ROAD. In Association of Asphalt Paving Technologists Proceedings (Vol. 48).

[11] Valdés, G., Pérez-Jiménez, F., Miró, R., Martínez, A., \& Botella, R. (2011). Experimental study of recycled asphalt mixtures with high percentages of reclaimed asphalt pavement (RAP). Construction and Building Materials, 25(3), 1289-1297.

[12] Santucci, L. (2007). Recycling asphalt pavements: A strategy revisited. Tech Topics, (8).

[13] Aravind, K., \& Das, A. (2007). Pavement design with central plant hot-mix recycled asphalt mixes. Construction and Building Materials, 21(5), 928-936.

[14] Chiu, C. T., Hsu, T. H., \& Yang, W. F. (2008). Life cycle assessment on using recycled materials for rehabilitating asphalt pavements. Resources, conservation and recycling, 52(3), 545-556.

[15] Kandahl, P. S., Rao, S. S., Watson, D. E., \& Young, B. (1995). Performance of recycled hot mix asphalt mixtures. 